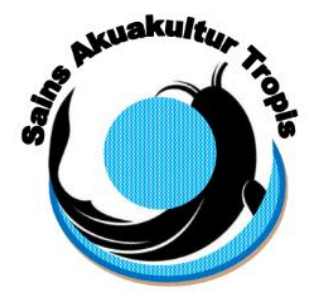

\author{
Jurnal Sains Akuakultur Tropis \\ Departemen Akuakultur \\ Fakultas Perikanan dan Ilmu Kelautan - Universitas Diponegoro \\ Jl. Prof. Soedarto, SH, Tembalang, Semarang 50275 \\ Telp. (024) 7474698, Fax.: (024) 7474698 \\ Email: sainsakuakulturtropis@gmail.com, sainsakuakulturtropis@undip.ac.id
}

\title{
PENGARUH PENAMBAHAN MADU DENGAN DOSIS BERBEDA DALAM MEDIA PENGENCER NaCI FISIOLOGIS TERHADAP KUALITAS SPERMA IKAN TAWES (Barbonymus gonionotus)
}

\begin{abstract}
The Effect of Addition Honey with Different Doses in Dilute Solution of NaCl on Sperm Quality of Silver Barb (Barbonymus gonionotus)
\end{abstract}

\author{
Oni Septiana Devi, Titik Susilowati*), Ristiawan Agung Nugroho \\ Departemen Akuakultur, \\ Fakultas Perikanan dan Ilmu Kelautan, \\ Jl. Prof. Soedarto, SH, Tembalang, Semarang, Jawa Tengah -50275, Telp/Fax. +62247474698 \\ * Corresponding author: susilowatibdp@gmail.com
}

\begin{abstract}
ABSTRAK
Ikan tawes (Barbonymus gonionotus) merupakan salah satu ikan budidaya air tawar asli Indonesia. Untuk meningkatkan produksi tawes diperlukan benih yang jumlahnya cukup banyak, kontinyu dan bermutu baik, untuk memperbesar jumlah produksi benih dapat dilakukan pengenceran spermatozoa, dengan harapan jumlah telur yang dapat dibuahi semakin banyak, karena secara teoritis satu ekor spermatozoa dapat membuahi satu sel telur, yang menjadi masalah adalah pilihan bahan pengencer spermatozoa, pada penelitian ini dipilih larutan pengencer $\mathrm{NaCl}$ fisiologi dan madu. Penambahan madu dalam larutan pengencer $\mathrm{NaCl}$ fisiologis diharapkan mampu meningkatkan kualitas sperma ikan tawes. Penelitian ini bertujuan untuk mengetahui pengaruh dan dosis terbaik madu dalam $\mathrm{NaCl}$ fisiologis terhadap kualitas sperma ikan tawes. Ikan uji yang digunakan dalam penelitian ini adalah 1 ekor induk jantan dan 1 ekor induk betina ikan tawes berusia 1-1,5 tahun. Penelitian ini menggunakan metode eksperimental Rancangan Acak Lengkap (RAL) terdiri dari 4 perlakuan dengan 3 kali pengulangan, yaitu: A (0 ml madu $+100 \mathrm{ml} \mathrm{NaCl}$ Fisiologis), B (0,2 ml madu + 99,8 ml NaCl Fisiologis), C (0,4 $\mathrm{ml}$ madu $+99,6 \mathrm{ml} \mathrm{NaCl}$ Fisiologis $), \mathrm{D}(0,6 \mathrm{ml}$ madu $+99,4 \mathrm{ml} \mathrm{NaCl}$ Fisiologis). Hasil penelitian menunjukkan bahwa pemberian madu dengan dosis berbeda dalam media pengencer $\mathrm{NaCl}$ Fisiologis berpengaruh nyata $(\mathrm{p}<$ 0,05) terhadap fertilisasi dan hatching rate ikan tawes. Perlakuan $\mathrm{D}(0,6 \mathrm{ml}$ madu $+99,4 \mathrm{ml} \mathrm{NaCl}$ Fisiologis $)$ memberikan nilai terbaik pada fertilisasi ikan tawes yaitu 90,67\% dan pada hatching rate ikan tawes yaitu sebesar $86,67 \%$.
\end{abstract}

Kata kunci: Madu; Motilitas; Fertilisasi; Hatching Rate; Tawes

\section{ABSTRACT}

Silver barb (Barbonymus gonionotus) is one of the freshwater fish that is native in Indonesia. To increase the production of silver barb, needed to quite a lot of seeds, continuous and good quality, to increase the amount of seed production, spermatozoa dilution can be done, with the hope that the number of fertilized eggs will increase, because theoretically one spermatozoa can fertilize an egg, the problem is the choice of spermatozoa thinners, in this study a solution of physiological NaCl diluent and honey was selected. The addition of honey in dilute solution of physiological $\mathrm{NaCl}$ is expected to be able to improve the quality of sperm of silver barb. The aim this research was to know the effect and the best honey dosage in physiological $\mathrm{NaCl}$ on sperm quality of silver barb. The test fish that will be used in this research is 1 broodstock male and 1 broodstock female with 1-1,5 years old. In this research, the Completely Randomized Design experimental method is used. This research also using 4 treatments and 3 repetitions. Those treatment were A $(0 \mathrm{ml}$ honey + $100 \mathrm{ml}$ physiological $\mathrm{NaCl}), \mathrm{B}(0,2 \mathrm{ml}$ honey $+99,8 \mathrm{ml}$ physiological $\mathrm{NaCl}), \mathrm{C}(0,4 \mathrm{ml}$ honey $+99,6 \mathrm{ml}$ physiological $\mathrm{NaCl}), \mathrm{D}(0,6 \mathrm{ml}$ honey $+99,4 \mathrm{ml}$ physiological $\mathrm{NaCl})$. The result of this research shows, addition of honey with different doses in dilute solution of physiological $\mathrm{NaCl}$ gave significant effect $(p<0,05)$ on fertilization rate and hatching rate of silver barb. The treatment $D(0,6 \mathrm{ml}$ honey $+99,4 \mathrm{ml}$ physiological $\mathrm{NaCl})$ gave the best on fertilization rate $90,67 \%$ and hatching rate $86,67 \%$. 
Keyword: Honey; Motility; Fertilization; Hatching Rate; Silver Barb

Article Received: 14-12-2018; Accepted: 10-01-2019

\section{PENDAHULUAN}

Ikan tawes (Barbonymus gonionotus) merupakan salah satu ikan asli perairan umum Indonesia dan telah lama dikenal sebagai ikan konsumsi penting (Kordi, 2010). Ikan tawes memiliki nilai gizi yang baik dengan kadar protein 27,87-28,10\% (Setiadi, 2001). Berdasarkan Badan Pusat Statistik Kabupaten Sleman (2016), data perkembangan produksi ikan tawes mengalami penurunan, yaitu pada tahun 2014 sebanyak 844,00 ton, tahun 2015 yaitu 374,10 ton, sedangkan tahun 2016 hanya 326,30 ton.

Untuk meningkatkan produksi tawes diperlukan benih yang jumlahnya cukup banyak, kontinyu dan bermutu baik, sebagai upaya memperbesar jumlah produksi benih dapat dilakukan pengenceran spermatozoa, dengan harapan jumlah telur yang dapat dibuahi semakin banyak.

Permasalahan dalam pengenceran spermatozoa adalah pemilihan bahan pengencer sperma agar kemampuan sperma dalam membuahi dan motilitasnya tetap prima, menurut Hijriana (2014), pengencer sperma ikan yang sering digunakan adalah $\mathrm{NaCl}$ fisiologi, larutan ini bersifat isotonis terhadap plasma semen. Sedangkan menurut Maulana et al. (2014), penyimpanan sperma yang diencerkan dengan larutan $\mathrm{NaCl} 1,3 \%$ hanya dapat bertahan maksimum selama 60 menit pada suhu ruang $\left(26^{\circ} \mathrm{C}\right)$ dan suhu dingin $\left(4^{\circ} \mathrm{C}\right)$, sedangkan tanpa pengenceran dapat bertahan selama 360 menit. Supaya daya hidup sperma lebih lama perlu diberikan nutrisi. Pada penelitian ini sebagai nutrisi ditambahkan dengan madu, menurut Arfah et al. (2015), menunjukkan bahwa pengenceran spermatozoa Pangasianodon hypopthalmus dengan pemberian madu kelengkeng dengan rasio pengenceran 1:50 menghasilkan viabilitas sperma 96,33 $\pm 0,58 \%$, tingkat fertilisasi $97,10 \pm 0,70 \%$, dan derajat penetasan $93,44 \pm 2,39 \%$, lebih lanjut dikatakan bahwa keberhasilan madu dalam pengenceran spermatozoa karena madu mengandung energi yang dibutuhkan oleh spermatozoa yaitu gula sederhana (monosakarida) seperti fruktosa dan glukosa. Penambahan fruktosa dan glukosa dalam pengenceran berguna untuk mendukung daya hidup spermatozoa pasca pengenceran, karena proses pembentukan Adenosin Trifosfat (ATP) dan Adenosin Difosfat (ADP) harus terus dilakukan agar motilitas dapat terus berlangsung. Gula sederhana (monosakarida) yang dibutuhkan oleh spermatozoa untuk menjaga kelangsungan hidupnya terkandung dalam madu (Tumanung et al., 2015). Madu mengandung 40,73\% fruktosa dan 27,11\% glukosa yang dapat digunakan spermatozoa sebagai sumber energi (Adalina, 2017).

Penelitian ini bertujuan untuk mengetahui pengaruh madu dengan dosis berbeda dalam media pengencer $\mathrm{NaCl}$ fisiologis terhadap kualitas sperma ikan tawes (B. gonionotus) dan mengetahui dosis terbaik madu dalam media pengencer $\mathrm{NaCl}$ fisiologis terhadap kualitas sperma ikan tawes (B. gonionotus).

\section{MATERI DAN METODE}

Ikan uji yang digunakan dalam penelitian ini adalah 1 ekor induk jantan ikan tawes dengan berat 639 gram dan 1 ekor induk betina ikan tawes dengan berat 815 gram yang berusia 1-1,5 tahun. Induk ikan tawes yang digunakan berasal dari Satuan Kerja Perbenihan dan Budidaya Ikan Air Tawar (PBIAT) Ngrajek, Magelang.

Metode yang digunakan dalam penelitian ini adalah metode eksperimental dengan rancangan percobaan yaitu Rancangan Acak Lengkap (RAL) terdiri dari 4 perlakuan 3 kali ulangan dan dilakukan selama 14 hari. Perlakuan dalam penelitian ini mengacu pada penelitian yang dilakukan oleh Tumanung et al. (2015) yaitu sebagai berikut :

Perlakuan A : $0 \mathrm{~mL}$ madu $+100 \mathrm{~mL} \mathrm{NaCl}$ Fisiologis

Perlakuan B : 0,2 mL madu $+99,8 \mathrm{~mL} \mathrm{NaCl}$ Fisiologis

Perlakuan C : 0,4 mL madu + 99,6 mL NaCl Fisiologis

Perlakuan D : 0,6 mL madu + 99,4 mL NaCl Fisiologis

Madu yang digunakan adalah madu hutan dihasilkan oleh lebah Apis dorsata atau lebah hutan, kandungan gula madu hutan sebesar $27,11 \%$ glukosa dan $40,73 \%$ fruktosa.

Prosedur dalam penelitian ini meliputi persiapan wadah, penanganan induk, pembuatan larutan pengencer sperma, pengambilan telur dan sperma ikan tawes, fertilisasi dan penetasan telur. Persiapan wadah penelitian meliputi pembersihan, pengeringan wadah dan setting alat. Induk yang akan digunakan diseleksi terlebih dahulu, selanjutnya dilakukan penanganan induk yaitu menimbang induk, menyuntikkan hormon ovaprim, dan memasukkan induk ke dalam hapa terpisah yang diberi aerasi selama 8 jam. Pengencer dibuat dengan menggunakan madu yang dilarutkan pada $\mathrm{NaCl}$ sesuai dengan dosis perlakuan, kemudian larutan pengencer dimasukkan dalam gelas plastik dan diberi label. Larutan pengencer diaduk menggunakan sendok teh hingga homogen. Pengambilan telur dan sperma dilakukan dengan cara di-stripping. Telur sampel yang digunakan yaitu 50 butir setiap perlakuan dan pengulangan. Sperma segar ditampung dalam mangkuk dan diamati secara makroskopis dan mikroskopis. Sperma ikan sebanyak $0,5 \mathrm{~mL}$ dilakukan pengenceran 50x menggunakan $\mathrm{NaCl}$ Fisiologis. Sperma $2 \mathrm{~mL}$ dimasukkan ke dalam larutan pengencer pada setiap perlakuan dan ulangan, dilanjutkan dengan memasukkan telur sebanyak 50 butir pada setiap perlakuan untuk dilakukan proses fertilisasi. Telur dan sperma diaduk menggunakan bulu ayam hingga homogen. Apabila telur telah terfertilisasi, larutan pengencer 
yang digunakan dibuang lalu diganti dengan air agar dapat dilakukan pengamatan fertilisasi. Telur yang terfertilisasi berwarna terang dan terdapat bintik hitam didalamnya, sedangkan telur yang tidak terfertilisasi akan berwarna keruh. Setelah dilakukan pengambilan data fertilisasi, telur dimasukkan ke dalam wadah penetasan. Penetasan telur ikan tawes dilakukan di dalam botol plastik 1,5 L yang diletakkan dalam baskom. Telur ikan tawes akan menetas setelah 24 jam. Selanjutnya dilakukan pengamatan hatching rate, dengan menghitung jumlah telur yang menetas.

\section{Pengumpulan Data}

\section{Pengamatan makroskopis sperma segar}

Pengamatan makroskopis sperma segar meliputi:

a. Volume sperma diukur langsung pada spuit yang digunakan sebagai wadah cairan sperma dengan ketelitian 0,1 mL (Arifiantini, 2012).

b. Warna sperma diamati secara visual menurut Tumanung et al. (2015), cairan spermatozoa ikan mas berwarna putih susu.

c. Konsistensi/kekentalan sperma diamati dengan cara menarik bagian bawah syringe serta dilihat apakah sperma bersifat kental, sedang atau cair. Metode yang digunakan untuk menentukan kekentalan sperma adalah dengan metode Akbar (2014), kriteria nilai konsistensi sperma sebagai berikut:

- Konsistensi encer: sperma akan segera kembali ke dasar tabung syringe.

- Konsistensi sedang: sperma akan kembali ke dasar tabung syringe dengan kecepatan yang lebih lambat dibandingkan yang pertama, sebagian sperma masih menempel di dinding.

- Konsistensi kental: sperma kembali ke dasar tabung syringe secara perlahan dan menyisakan sebagian sperma di pinggiran tabung.

d. pH sperma diukur menggunakan special indicator paper (Merck). Sperma di dalam spuit dikeluarkan sedikit ke dalam cawan petri, lalu $\mathrm{pH}$ paper dicelupkan ke dalam sperma, perubahan warna pada $\mathrm{pH}$ paper dicocokkan dengan kotak indikator special indicator paper (Merck) (Arifiantini, 2012).

\section{Pengamatan mikroskopis sperma}

Pengamatan motilitas spermatozoa yaitu motilitas sperma, dilakukan dengan mengambil satu tetes sperma dari setiap perlakuan menggunakan pipet tetes dan diletakkan pada slide glass lalu ditutup dengan cover glass. Selanjutnya dilakukan pengamatan menggunakan mikroskop.

Menurut Susilawati (2011), kriteria penilaian gerak massa spermatozoa antara lain:

a. Sangat baik (+++) terlihat adanya gelombang besar, banyak, gelap, tebal, dan aktif seperti gumpalan awan hitam dekat waktu hujan yang bergerak cepat berpindah-pindah tempat;

b. Baik (++) bila terdapat gelombang-gelombang kecil tipis, jarang, kurang jelas dan bergerak lamban;

c. Kurang baik (+), jika tidak terlihat gelombang melainkan gerakan-gerakan individual aktif progresif; Buruk (0), bila hanya sedikit ada gerakan-gerakan individual.

Penilaian kualitatif gerak massa (motilitas) spermatozoa menggunakan acuan diatas. Untuk mempermudah dalam penghitungan hasil rata-rata motilitas dan pembuatan grafik maka data tersebut diubah menjadi kuantitatif, dengan cara pada tingkat +++ diubah menjadi $3,++$ diubah menjadi $2,+$ diubah menjadi 1 dan tingkat 0 yaitu 0 .

3. Fertilisasi

Data fertilisasi (Fr) yang diambil yaitu menghitung jumlah telur yang dibuahi pada masing-masing perlakuan. Untuk menentukan tingkat fertilisasi pada setiap perlakuan, rumus yang digunakan (Nurman, 1998):

\section{Hatching rate}

$$
\operatorname{Fr}(\%)=\frac{\text { Jml. telur dibuahi }}{\text { Jml. telur sampel }} \times 100 \%
$$

Dalam menentukan tingkat penetasan telur data yang diperlukan adalah banyaknya telur yang menetas pada masing-masing perlakuan. Daya tetas telur (HR) dihitung berdasarkan persamaan Effrizal (1998):

\section{Kualitas air penetasan telur}

$$
\operatorname{HR}(\%)=\frac{\mathrm{Jml} \text {. telur menetas }}{\mathrm{Jml} \text {. telur sampel }} \times 100 \%
$$

Pengamatan kualitas air meliputi suhu, oksigen terlarut (DO), dan tingkat keasaman (pH). Pengamatan kualitas air dilakukan setiap tiga kali sehari yaitu pada pagi, siang dan sore, menggunakan alat Water Quality Checker (WQC) dengan cara mencelupkan ujung alat indikator ke dalam air kemudian menunggu hingga konstan dan mencatat nilainya. Pengukuran variabel kualitas air pada pagi hari jam 08.00, 12.00 dan 16.00.

\section{Analisis Data}

Data motilitas yang diperoleh dianalisis dengan cara deskriptif, yaitu memberikan gambaran yang jelas tentang hal-hal yang terjadi secara kualitatif dilakukan selama percobaan berlangsung. Data fertilisasi (daya membuahi sel telur) dan hatching rate (daya tetas telur) terlebih dahulu dilakukan uji normalitas, uji 
homogenitas, dan uji additivitas guna mengetahui bahwa data bersifat normal, homogen dan aditif untuk dilakukan uji analisa ragam. Selanjutnya dianalisis menggunakan analisa ragam (ANOVA), selang kepercayaan yang digunakan adalah 95\%. Apabila perlakuan berpengaruh nyata pada analisis ragam (ANOVA), maka dilanjutkan uji nilai wilayah ganda Duncan untuk mengetahui perbedaan antar perlakuan. Data kualitas air dianalisis secara deskriptif untuk diperbandingkan dengan nilai kelayakan sebagai data pendukung daya tetas telur.

\section{HASIL}

a. Makroskopis sperma segar ikan tawes (B. gonionotus)

Berdasarkan penelitian yang telah dilakukan, diperoleh data makroskopis sperma segar ikan tawes. Hasil pengamatan makropkopis sperma segar ikan tawes tersaji pada Tabel 1.

Tabel 1. Hasil Makroskopis Sperma Segar Ikan Tawes (B. gonionotus)

\begin{tabular}{lll}
\hline No & Parameter & Hasil \\
\hline 1. & Volume & $3 \mathrm{~mL}$ \\
2. & Warna & Putih susu \\
3. & Kekentalan & Sedang \\
4. & $\mathrm{pH}$ & 8 \\
\hline
\end{tabular}

\section{b. Mikroskopis sperma ikan tawes (B. gonionotus)}

Pengamatan mikroskopis sperma ikan tawes yaitu motilitas spermatozoa sperma tanpa perlakuan dan sperma dengan perlakuan. Berdasarkan penelitian yang telah dilakukan, motilitas spermatozoa ikan tawes tersaji pada Gambar 1, 2 dan hasil pengamatan motilitas spermatozoa tersaji pada Gambar 3.

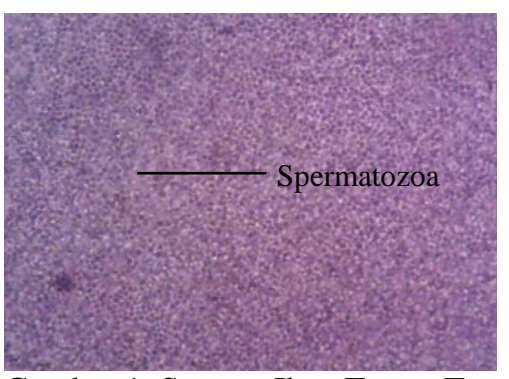

Gambar 1. Sperma Ikan Tawes Tanpa Perlakuan (Pembesaran 400x)

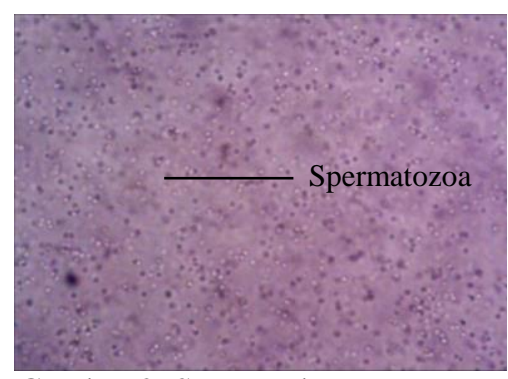

Gambar 2. Sperma Ikan Tawes dengan Pengenceran $\mathrm{NaCl} 50 x$ (Pembesaran 400x)

Berdasarkan gambar diatas (gambar 3) menunjukkan bahwa sperma ikan tawes yang tidak dilakukan pengenceran tingkat kepadatannya sangat tinggi sedangkan sperma yang dilakukan pengenceran tingkat kepadatannya rendah (gambar 4).

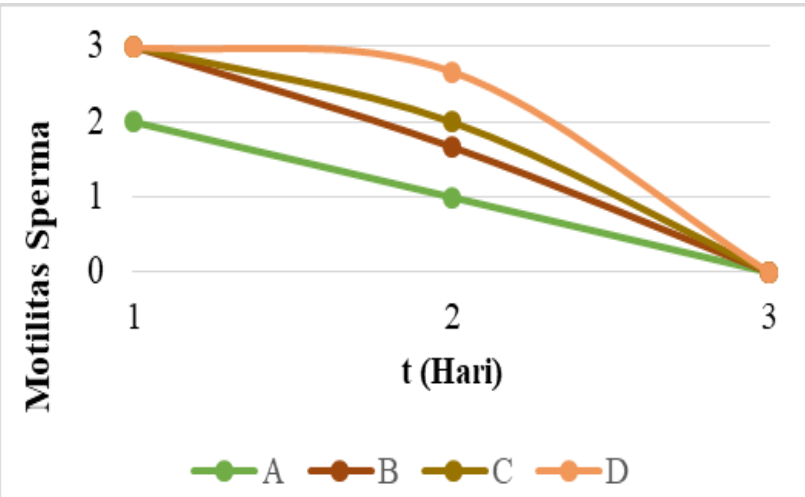

Gambar 3. Grafik Rata-rata Motilitas Sperma Ikan Tawes (B. gonionotus)

Grafik diatas menunjukkan hasil dari rata-rata motilitas sperma ikan tawes dari hari ke-1 sampai hari ke-3 yaitu pada pengamatan hari pertama terlihat kondisi perlakuan B, C dan D masih sangat baik (3) motilitasnya, sedangkan pada perlakuan A kondisi sperma baik (2). Pengamatan pada hari kedua, motilitas sperma terlihat sudah mengalami penurunan, ditunjukkan pada perlakuan C dan D kondisi sperma masih dalam kategori baik (2) sedangkan pada perlakuan A dan B (1) kondisinya kurang baik. Pengamatan motilitas pada hari ketiga semua perlakuan mengalami penurunan menjadi kategori buruk (0). 


\section{c. Fertilisasi}

Berdasarkan penelitian yang telah dilakukan, diperoleh data tingkat fertilisasi ikan tawes. Hasil perhitungan persentase tingkat fertilisasi tersaji pada Gambar 4.

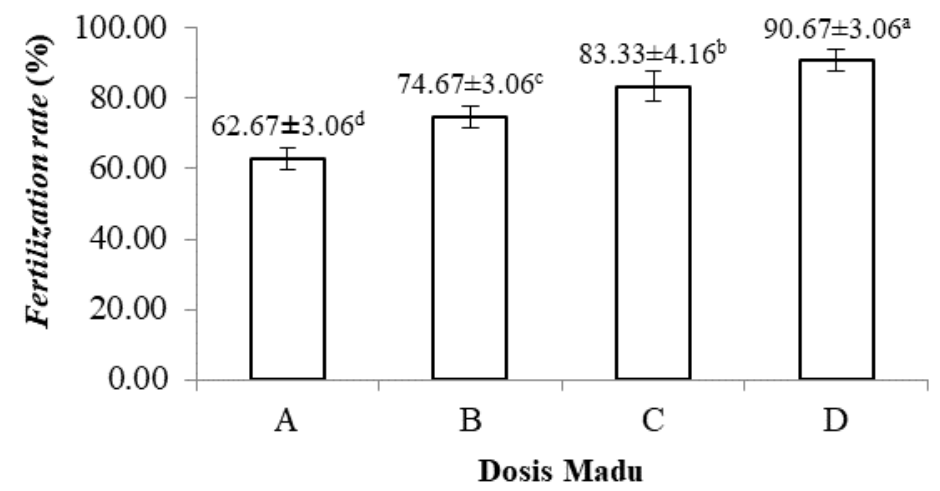

Gambar 4. Rata-rata Persentase Fertilisasi Ikan Tawes (B. gonionotus)

Keterangan: Nilai dengan superscript yang berbeda menunjukkan adanya perbedaan yang nyata

Berdasarkan grafik diatas menunjukkan bahwa nilai rerata tingkat fertilisasi ikan tawes tertinggi yaitu pada perlakuan $\mathrm{D}(0,6 \mathrm{~mL}$ madu $+99,4 \mathrm{~mL} \mathrm{NaCl}$ Fisiologis $)$ yaitu $90,67 \%$, diikuti perlakuan $\mathrm{C}(0,4 \mathrm{~mL}$ madu + $99,6 \mathrm{~mL} \mathrm{NaCl}$ Fisiologis) yaitu $83,33 \%$, perlakuan $\mathrm{B}(0,2 \mathrm{~mL}$ madu $+99,8 \mathrm{~mL} \mathrm{NaCl}$ Fisiologis $)$ yaitu 74,67\%, dan terendah pada perlakuan $\mathrm{A}(0 \mathrm{~mL}$ madu $+100 \mathrm{~mL} \mathrm{NaCl}$ Fisiologis $)$ yaitu $62,67 \%$.

\section{d. Hatching rate}

Berdasarkan penelitian yang telah dilakukan diperoleh data HR (hatching rate) ikan tawes. Hasil perhitungan rata-rata persentase HR tersaji pada Gambar 5.

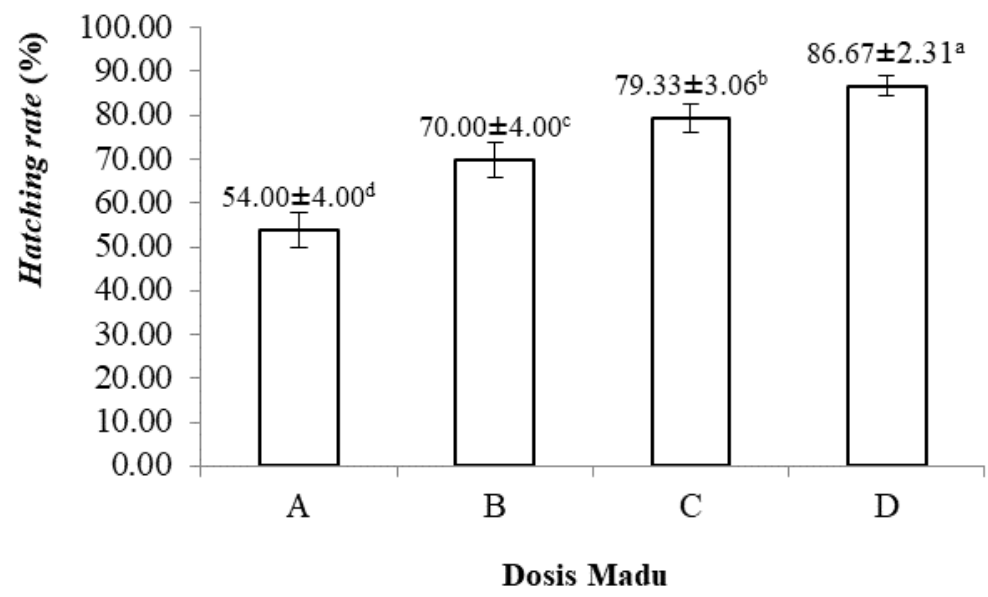

Gambar 5. Rata-rata Persentase Hatching Rate Ikan Tawes (B. gonionotus)

Keterangan: Nilai dengan superscript yang berbeda menunjukkan adanya perbedaan yang nyata.

Grafik diatas menunjukkan hasil perhitungan rata-rata persentase daya tetas telur ikan tawes dalam ulangan dan perlakuan yang tertinggi yaitu pada perlakuan $\mathrm{D}(86,67 \%)$, diikuti perlakuan $\mathrm{C}(79,33 \%)$, perlakuan B $(70,00 \%)$, dan terendah pada perlakuan A $(54,00 \%)$.

\section{e. Kualitas air}

Hasil pengukuran terhadap kualitas air pada wadah penetasan telur ikan tawes diantaranya suhu, $\mathrm{pH}$ dan oksigen terlarut dilakukan pada pukul 08.00, 12.00 dan 17.00 tersaji pada Tabel 2.

Tabel 2. Pengukuran Kualitas Air Penetasan Telur Ikan Tawes (B. gonionotus)

\begin{tabular}{|c|c|c|c|c|c|}
\hline \multirow{2}{*}{ Variabel } & \multicolumn{4}{|c|}{ Perlakuan } & \multirow[b]{2}{*}{ Pustaka } \\
\hline & $\mathrm{A}$ & B & $\mathrm{C}$ & $\mathrm{D}$ & \\
\hline Suhu $\left({ }^{0} \mathrm{C}\right)$ & $25-27$ & $25-27$ & $25-27$ & $25-27$ & $25-30 *$ \\
\hline $\mathrm{pH}$ & 7 & 7 & 7 & 7 & $6,5-8,5^{*}$ \\
\hline $\mathrm{DO}(\mathrm{mg} / \mathrm{l})$ & $4-6$ & $4-6$ & $4-6$ & $4-6$ & $>5^{*}$ \\
\hline
\end{tabular}

Keterangan: *SNI (1999) 


\section{PEMBAHASAN}

\section{a. Makroskopis sperma segar ikan tawes (B. gonionotus)}

Pengamatan makroskopis sperma segar ikan tawes dilakukan untuk mengetahui kondisi secara fisik sperma ikan tawes, dimana hal tersebut dapat dijadikan penentu kualitas sperma. Volume sperma segar yang dihasilkan dari ikan tawes yaitu sebanyak $3 \mathrm{~mL}$, yang berasal dari 1 ekor induk jantan dengan berat 639 gram dan berusia 1-1,5 tahun. Usia ikan dapat mempengaruhi volume sperma, hal ini dikarenakan tiap spesies ikan mencapai tahap kedewasaan (mencapai kematangan gonad pertama kali, pada usia yang berbeda-beda). Berdasarkan penelitian yang telah dilakukan volume sperma yang dihasilkan lebih banyak daripada hasil penelitian Utami (2010), yaitu volume semen segar ikan tawes yang didapatkan selama penelitian berkisar antara 0,6-0,8 mL, dengan rata-rata volumenya sebesar $0,72 \pm 0,11 \mathrm{~mL}$ per individu. Hal ini diperkuat oleh Kurniawan et al. (2013), yang menyatakan perbedaan volume sperma diduga terdapat faktor pengaruh dari kondisi ikan, manajemen pakan yang diberikan dan lingkungan sekitar.

Secara visual sperma segar ikan tawes berwarna putih susu dan derajat keasaman $(\mathrm{pH})$ sperma ikan tawes yang terukur yaitu 8 . Konsistensi sperma yang diperoleh sedang, yaitu sperma tidak terlalu kental dimana saat dilakukan pengamatan berdasarkan Arifiantini (2012), sperma kembali ke dasar tabung syringe dengan kecepatan yang lebih lambat dibandingkan pada sperma yang encer, sebagian sperma masih menempel pada dinding syringe. Warna semen sperma tersebut sesuai sedangkan nilai $\mathrm{pH}$ yang diperoleh berbeda dengan hasil penelitian Akbar (2014), yaitu semen segar ikan tawes berwarna putih susu, hal ini menunjukkan warna dan konsistensi semen tersebut memiliki kualitas yang baik. Nilai $\mathrm{pH}$ yang diperoleh berkisar antara 6,7-6,83 nilai ini termasuk asam, interval $\mathrm{pH}$ normal untuk ikan cyprinidae adalah 7,5-8. Perbedaan nilai $\mathrm{pH}$ yang diperoleh menunjukkan bahwa variasi nilai $\mathrm{pH}$ juga dapat terjadi dalam spesies yang sama. Menurut Susilawati (2011), konsistensi sperma dipengaruhi oleh umur, lingkungan, status kesehatan, musim, dan spesies yang berbeda.

\section{b. Mikroskopis sperma ikan tawes (B. gonionotus)}

Penghitungan motilitas spermatozoa lebih bersifat subyektif, oleh sebab itu untuk mengeliminir subyektifitas pengamat, maka pada pengamatan ini dilakukan pelatihan dan diuji lebih dari satu orang. Pengamatan mikroskopis yang dilakukan yaitu pada sperma tanpa pengencer (segar) dan sperma yang telah diencerkan. Hasil yang diperoleh pada sperma segar yaitu tingkat kepadatan spermatozoa sangat tinggi, dapat dilihat pada Gambar 3 sedangan sperma yang tidak dilakukan pengenceran tingkat kepadatannya rendah. Hasil dari pengamatan mikroskopis berkaitan dengan hasil makroskopis, dimana hasil dari makroskopis menunjukkan fisiologi dari spermatozoa yang dapat dijadikan penunjang untuk menentukan kualitas spermatozoa ikan tawes.

Berdasarkan pada grafik rata-rata motilitas sperma ikan tawes (gambar 5) menunjukkan bahwa dari hari ke-1 sampai hari ke-3 mengalami penurunan, hal ini disebabkan ketersediaan nutrisi yang dibutuhkan oleh sperma semakin terbatas sehingga motilitas sperma semakin hari semakin menurun. Hal ini diperkuat oleh Kurniawan et al. (2013), semakin lama waktu penyimpanan motilitas akan terus mengalami penurunan karena persediaan energi semakin terbatas. Menurut Lismawati et al. (2016), spermatoza dari pasca penyimpanan masih mampu bertahan dan masih layak untuk dilanjutkan ketahap fertilisasi dan daya tetas telur, namun semakin lama disimpan kualitas spermatozoa pasca penyimpanan akan menurun, tetapi tingkat motilitas tinggi.

Tingkat motilitas terendah yaitu pada perlakuan A $(0 \mathrm{~mL}$ madu $+100 \mathrm{~mL} \mathrm{NaCl}$ Fisiologis $)$. Seiring dengan meningkatnya penambahan konsentrasi madu dalam pengenceran sperma ikan tawes, motilitas spermatozoa semakin meningkat. Hal tersebut menunjukkan bahwa penambahan madu dalam media pengencer $\mathrm{NaCl}$ fisiologis memberikan pengaruh terhadap motilitas spermatozoa ikan tawes, dikarenakan gula sederhana (monosakarida) yang dibutuhkan oleh spermatozoa terkandung di dalam madu. Hal ini diperkuat oleh Tumanung et al. (2015), bahwa energi yang dibutuhkan oleh spermatozoa disediakan oleh gula sederhana (monosakarida) seperti fruktosa dan glukosa. Penambahan fruktosa atau glukosa dalam pengenceran berguna untuk mendukung daya hidup spermatozoa pasca pengenceran. Gula sederhana (monosakarida) yang dibutuhkan oleh spermatozoa untuk menjaga kelangsungan hidupnya terkandung dalam madu.

Spermatozoa menyerap glukosa dan fruktosa melalui membran plasma. Membran plasma merupakan struktur yang bersifat selective permeable, yaitu dapat ditembus oleh beberapa jenis zat, molekul dan ion tertentu. Proses glukosa dan fruktosa menembus membran plasma disebut proses transpor membran. Transpor membran terbagi menjadi dua yaitu transpor pasif (osmosis, difusi, dan difusi difasilitasi) dan aktif (menggunakan energi dari sel). Glukosa dan fruktosa bersifat polar sehingga untuk menembus membran sel melalui proses transpor pasif yaitu oleh carrier mediated diffusion (difusi difasilitasi). Protein carriers pada membran plasma berfungsi untuk memindahkan glukosa dan fruktosa dari ekstraseluler menuju intraseluler. Hal ini diperkuat oleh Sumardi et al. (2007), menyatakan bahwa protein carrier mengangkut senyawa-senyawa yang tidak bisa melewati lapisan lipid secara langsung, misalnya ion-ion dan senyawa lain yang bermuatan polar. Bilayer lipid sangat tidak permeabel terhadap semua ion sekalipun ion kecil seperti $\mathrm{H}+$ dan $\mathrm{Na}+$, sehingga pengangkutan harus melalui protein carrier. Tahapan-tahapan dalam difusi berfasilitas, diantaranya tahap awal yaitu tahap pengenalan (recognition) dari molekul metabolit yang akan mengalami transpor ke dalam sel dengan protein carrier, tahap pengikatan yaitu molekul carrier yang terdapat di dalam membran akan membentuk kompleks spesifik dengan metabolit yang berada di luar membran, tahap gerakan yaitu gerakan dari kompleks 
tersebut ke bagian yang lebih dalam dari membran, cara geraknya dapat melalui mekanisme difusi, rotasi, osilasi dan gerakan lainnya dan tahap pelepasan yaitu pada tahap ini terjadi pelepasan metabolit ke dalam sel melalui mekanisme asosiasi, disosiasi, dan translokasi.

Motilitas spermatozoa merupakan salah satu faktor yang mempengaruhi kualitas sperma. Motilitas spermatozoa memiliki kaitan dengan fertilisasi (pembuahan sel telur) ikan tawes, dimana motilitas yang bergerak aktif dan cepat tingkat membuahi sel telurnya tinggi. Menurut Bozkurt et al. (2009), motilitas spermatozoa ikan dapat berbeda, meskipun berasal dari spesies ataupun individu yang sama. Hal terebut dikarenakan kualitas spermatozoa dipengaruhi oleh beberapa faktor, diantaranya usia, ukuran, dan fisiologis ikan. Nilai motilitas yang berbeda juga dapat disebabkan oleh metode pengamatan yang digunakan. Metode pengamatan yang digunakan dalam penelitian adalah metode subjektif. Oleh karena itu, perbedaan dalam interpretasi data yang diperoleh sangat mungkin terjadi dikarenakan faktor subjektivitas dan pengalaman peneliti.

\section{c. Fertilisasi}

Pemberian madu dengan dosis berbeda dalam media pengencer $\mathrm{NaCl}$ fisiologis diketahui memberikan pengaruh terhadap kualitas spermatozoa ikan tawes, yang berkolerasi dengan kemampuan spermatozoa membuahi sel telur. Hal tersebut didasarkan pada hasil yang diperoleh selama penelitian. Hasil perhitungan analisis varian yang diperoleh, yaitu data rerata fertilisasi ikan tawes didapatkan hasil $F_{\text {hitung }}>F_{\text {tabel }}$. Hal tersebut menunjukkan perlakuan dalam penelitian memberikan pengaruh nyata $(\mathrm{p}<0,05)$ terhadap fertilisasi ikan tawes. Salah satu faktor yang mempengaruhi keberhasilan fertilisasi ikan tawes yaitu kualitas spermatozoa. Parameter kualitas spermatozoa yang menentukan keberhasilan fertilisasi diantaranya motilitas. Spermatozoa yang memiliki tingkat motilitas tinggi dapat membuahi sel telur lebih banyak, dikarenakan lama waktu aktivitas sperma menjadi lebih panjang sehingga sperma memperoleh banyak waktu untuk menemukan dan membuahi sel telur. Sesuai dengan pendapat Lismawati et al. (2016), bahwa fertilisasi dapat didukung oleh kualitas spermatozoa yang baik. Kualitas sperma (konsentrasi spermatozoa, motilitas spermatozoa dan komposisi cairan plasma semen) akan berpengaruh terhadap fertilisasi spermatozoa. Tingkat fertilisasi nampaknya mengikuti apa yang terjadi pada tingkat kualitas sperma, jika motilitas yang meningkat memberikan fertilisasi yang tinggi. Hal ini diperkuat oleh Utami (2010), bahwa kualitas spermatozoa yang rendah menyebabkan keberhasilan fertilisasi juga rendah.

Nilai rata-rata persentase fertilisasi ikan tawes menunjukkan bahwa pemberian madu dengan dosis berbeda dalam media pengencer $\mathrm{NaCl}$ fisiologis dapat meningkatkan nilai fertilisasi ikan tawes. Berdasarkan hasil yang diperoleh, diketahui nilai fertilisasi terbaik yaitu pada perlakuan D $(90,67 \%)$, sedangkan nilai terendah pada perlakuan A $(62,67 \%)$. Nilai persentase fertilisasi tersebut lebih tinggi dibandingkan dengan penelitian Tumanung et al. (2015), bahwa pada ikan mas dengan perlakuan yang sama nilai fertilisasi terbaik yaitu pada perlakuan D (84,00\%) dan nilai terendah yaitu perlakuan A (70,50\%), pada penelitian Lismawati et al. (2016), pada ikan tawes dengan ekstender berbeda (kelapa muda dan $\mathrm{NaCl}$ ) nilai fertilisasi yang diperoleh lebih rendah, fertilisasi terbaik yaitu pada perlakuan P4 (64,3\%) dan terendah perlakuan P1 (25\%) dan pada penelitian yang telah dilakukan oleh Utami (2010), nilai rerata persentase fertilisasi ikan tawes segar (prakrioreservasi) dengan perlakuan menggunakan susu skim dan metanol yaitu 83,63\%. Hal ini menunjukkan bahwa proses pembuahan sel telur setiap individu maupun pada spesies ikan yang berbeda sangat dipengaruhi oleh kualitas telur, kuantitasitas spermatozoa dan lingkungan. Sesuai dengan pendapat Utami (2010), bahwa kuantitas spermatozoa juga merupakan salah satu parameter keberhasilan fertilisasi, selain kualitas spermatozoa. Keberhasilan fertilisasi juga dipengaruhi oleh faktor lain, diantaranya rasio pengenceran, jenis ekstender, dan kualitas sel telur.

Berdasarkan hasil uji wilayah Duncan pada pengamatan fertilisasi ikan tawes, menunjukkan bahwa perlakuan D berbeda nyata dengan perlakuan C dan berbeda sangat nyata dengan perlakuan B dan A. Sedangkan perlakuan $\mathrm{C}$ berbeda nyata dengan perlakuan $\mathrm{B}$, dan berbeda sangat nyata dengan perlakuan A. Perlakuan B berbeda sangat nyata dengan perlakuan A. Penggunaan 0,6 $\mathrm{mL}$ madu $+99,4 \mathrm{~mL} \mathrm{NaCl}$ Fisiologis (D), memberikan hasil terbaik terhadap fertilisasi ikan tawes dibandingkan dengan konsentrasi madu yang lain, hal ini diduga madu mampu memberikan sumber energi yang diperlukan untuk mendukung kelangsungan hidup spermatozoa. Menurut Wulandari (2017), madu mengandung banyak mineral seperti natrium, kalsium, magnesium, alumunium, besi, fosfor, dan kalium. Vitamin yang terdapat dalam madu adalah thiamin (B1), riboflavin (B2), asam askorbat (C), piridoksin (B6), niasin, asam pantotenat, biotin, asam folat, dan vitamin K. Sedangkan enzim yang penting dalam madu adalah enzim diastase, invertase, glukosa oksidase, peroksidase, dan lipase. Selain itu unsur kandungan madu lainnya adalah memiliki zat antibiotik atau antibakteri. Hal ini diperkuat oleh Tumanung et al. (2015), bahwa energi yang dibutuhkan oleh spermatozoa disediakan oleh gula sederhana (monosakarida) seperti fruktosa dan glukosa yang terkandung di dalam madu.

Larutan $\mathrm{NaCl}$ fisiologis dalam penelitian ini juga dapat mempertahankan sperma dalam keadaan yang isotonis, sperma tidak mengalami metabolisme yang tinggi, dan energi menjadi tersimpan. Data persentase fertilisasi yang diperoleh menunjukkan adanya korelasi positif antara kualitas spermatozoa dengan tingkat fertilisasi. Hal ini diperkuat oleh Arfah et al. (2015), bahwa larutan $\mathrm{NaCl}$ memberi sifat buffer, mempertahankan pH sperma dalam suhu kamar, bersifat isotonis dengan cairan sel, melindungi spermatozoa terhadap coldshock dan penyeimbangan electron yang sesuai. Sesuai dengan pendapat Susilawati (2010), syarat yang harus dimiliki oleh setiap bahan pengencer, yaitu mempunyai daya preservasi tinggi, mengandung unsur yang sifat fisik dan 
kimiawinya hampir sama dengan sperma dan tidak mengandung zat yang bersifat racun bagi spermatozoa, dapat mempertahankan daya fertilisasi spermatozoa, dan tidak terlalu kental sehingga menghambat fertilisasi. Syarat dari pengencer lainnya adalah mengandung sumber energi, bersifat isotonis, mangandung buffer, melindungi dari pengaruh pendinginan secara cepat, dan menghambat pertumbuhan bakteri.

\section{d. Hatching rate}

Derajat penetasan (HR) merupakan persentase telur yang menetas setelah waktu tertentu. Berdasarkan hasil analisis varian didapatkan hasil $F_{\text {hitung }}>F_{\text {tabel, }}$, hal ini menunjukkan bahwa perbedaan perlakuan memberikan pengaruh yang nyata $(\mathrm{p}<0,05)$ terhadap HR ikan tawes. HR dipengaruhi oleh faktor internal berupa kerja hormon dan volume kuning telur serta faktor eksternal berupa suhu, oksigen terlarut dan intensitas cahaya. Menurut Zairin et al. (2005), peningkatan suhu, peningkatan intensitas cahaya dan atau penurunan tekanan oksigen diduga dapat meningkatkan jumlah penetasan. Menurut Rachimi et al. (2016), bahwa faktor internal yang mempengaruhi tingkat penetasan telur adalah perkembangan embrio yang terhambat akibat sperma yang kurang motil dan perkembangan embrio yang terhambat karena kualitas spermatozoa dan telur kurang baik.

Nilai rata-rata persentase HR ikan tawes terbaik terdapat pada perlakuan D $(86,67 \%)$, dan yang terendah terdapat pada perlakuan A $(54,00 \%)$. Hal ini menunjukkan bahwa pemberian madu dengan dosis berbeda dalam media pengencer $\mathrm{NaCl}$ fisiologis dapat memberikan pengaruh terhadap daya tetas telur ikan tawes. Nilai persentase HR tersebut lebih tinggi dibandingkan dengan penelitian Tumanung et al. (2015), pada ikan mas dengan perlakuan yang sama diperoleh hasil daya tetas telur tertinggi pada perlakuan D yaitu $(82,33 \%)$ dan terendah perlakuan A $(66,67 \%)$, sedangkan pada penelitian Nainggolan et al. (2015), pada ikan nila dengan perlakuan berbeda diperoleh hasil penetasan telur terbaik pada perlakuan $\mathrm{D}(0,70 \mathrm{~mL}$ madu dalam $99,30 \mathrm{~mL}$ $\mathrm{NaCl}$ fisiologis) yaitu 77,33\% dan terendah pada perlakuan A (0 mL madu) yaitu 69,33\%. Menurut Zairin et al. (2005), faktor yang diduga menyebabkan rendahnya derajat penetasan adalah telur tidak berkembang setelah dibuahi, perubahan kemampuan fisiologis telur saat embriogenesis, atau dapat pula disebabkan karena kerusakan telur sampel saat dipindahkan ke media penetasan.

Berdasarkan hasil uji wilayah Duncan menunjukkan, bahwa perlakuan D berbeda nyata dengan perlakuan $\mathrm{C}$ dan berbeda sangat nyata dengan perlakuan B dan A. Perlakuan C berbeda nyata dengan perlakuan B, dan berbeda sangat nyata dengan perlakuan A. Sedangkan perlakuan B berbeda sangat nyata dengan perlakuan A. Hasil yang diperoleh pada penetasan telur ikan tawes jika dilihat dari data persentase fertilisasi ikan tawes, diduga persentase fertilisasi yang tertinggi akan diikuti oleh penetasan yang tinggi, dan persentase fertilisasi yang terendah akan diikuti oleh penetasan yang rendah pula. Hal ini menunjukkan bahwa fertilisasi mempengaruhi HR ikan tawes. Selain hal tersebut terdapat juga faktor lainnya yang dapat mempengaruhi HR ikan tawes, yaitu kualitas telur, lingkungan dan media penetasan. Media penetasan yang mempengaruhi HR ikan tawes diantaranya wadah dan aerasi yang digunakan. Wadah yang digunakan sebagai media penetasan telur ikan tawes harus disesuaikan dengan sifat telur, telur ikan tawes bersifat melayang sehingga wadah yang digunakan dalam penelitian ini merupakan hasil modifikasi dari botol air mineral 1,5 L, dan modifikasi aerasi yang diletakkan pada tutup botol. Aerasi juga dapat mempengaruhi HR ikan tawes, dikarenakan aerasi yang terlalu kuat dapat menghancurkan telur ikan tawes dan aerasi terlalu kecil menyebabkan ikan tawes sulit melayang, sehingga telur menempel pada dinding botol dan telur tidak menetas. Faktor lingkungan yang mempengaruhi HR ikan tawes yaitu kualitas air diantaranya suhu, $\mathrm{pH}$, dan DO. Menurut Nainggolan et al. (2015), faktor internal yang berpengaruh terhadap daya tetas telur adalah perkembangan embrio yang terhambat karena kualitas spermatozoa dan telur kurang baik. Sedangkan faktor eksternal yang berpengaruh terhadap penetasan telur adalah lingkungan yang di dalamnya terdapat temperatur air, oksigen terlarut, $\mathrm{pH}$ dan amoniak. Daya tetas telur ikan selalu ditentukan oleh pembuahan sperma, kecuali bila ada faktor lingkungan yang mempengaruhinya.

\section{e. Kualitas air}

Variabel kualitas air yang diamati antara lain adalah suhu, $\mathrm{pH}$, dan DO. Hasil pengukuran pada variabel suhu media penetasan telur ikan tawes berkisar antara $25-27^{\circ} \mathrm{C}$. Suhu yang dihasilkan dapat dikatakan stabil dan tidak mengalami fluktuasi yang tinggi. Hal ini disebabkan karena penetasan telur dilakukan di dalam ruangan (indoor) sehingga suhu media penetasan telur cukup stabil. Kisaran suhu juga masih dalam batas optimum untuk penetasan telur ikan tawes. Suhu berpengaruh terhadap penetasan telur ikan tawes, diduga suhu yang terlalu tinggi dapat menyebabkan terjadinya abnormalitas pada telur sedangkan pada suhu yang terlalu rendah dapat memperlambat proses penetasan. Menurut SNI (1999), bahwa suhu optimal untuk penetasan telur adalah 25$30^{\circ} \mathrm{C}$. Hal ini diperkuat oleh Farida et al. (2016), bahwa suhu terlalu tinggi dapat mengganggu aktivitas enzim penetasan pada telur dan mengakibatkan pengerasan pada chorion, sehingga menghambat proses penetasan telur dan dapat mengakibatkan terjadinya keabnormalitasan (cacat) pada larva ikan yang dihasilkan. Suhu yang terlalu tinggi dapat menyebabkan larva prematur (lebih cepat menetas) sehingga larva yang dihasilkan kurang siap dalam menghadapi lingkungannya. Suhu mempunyai peranan yang sangat penting dalam penetasan telur ikan, cepat atau lambatnya proses penetasan telur tergantung suhu air di sekitarnya, dimana semakin tinggi suhu maka semakin cepat telur menetas sebaliknya jika suhu rendah maka kemungkinan telur menetas jumlahnya sedikit. Perubahan suhu yang mencolok dapat mempengaruhi proses metabolisme, karena pada suhu yang tinggi kecepatan metabolisme akan menurun sesuai dengan mekanisme kerja enzim. Suhu merupakan faktor 
lingkungan yang dapat mempengaruhi pertumbuhan rata-rata dan menentukan waktu penetasan serta berpengaruh langsung pada proses perkembangan embrio dan larva.

Parameter kualitas air merupakan media hidup yang sangat penting dalam penetasan telur ikan, karena akan mempengaruhi perkembangan telur, daya tetas telur dan penetasan telur ikan. Kualitas air yang buruk dapat menghambat penetasan telur ikan bahkan menyebabkan kematian. Faktor lain yang juga berpengaruh yaitu derajat keasaman $(\mathrm{pH})$. Nilai $\mathrm{pH}$ yang dihasilkan pada media penetasan telur ikan tawes selama penelitian yaitu 7. Nilai pH tersebut masih dalam kisaran optimal untuk penetasan telur ikan tawes. Hal ini diperkuat oleh SNI (1999), bahwa nilai pH optimum untuk penetasan telur yaitu 6,5-8,5.

Secara umum kisaran kualitas air selama penelitian masih dalam kisaran normal. Hasil pengukuran nilai oksigen terlarut atau DO yaitu berkisar antara 4-6 mg/L. Oksigen terlarut dibutuhkan dalam proses metabolisme embrio di dalam telur. Menurut SNI (1999), nilai DO optimum untuk penetasan telur yaitu minimal $5 \mathrm{mg} / \mathrm{L}$. Menurut Hutagalung et al. (2017), oksigen terlarut yang cukup sangat penting dalam pembenihan karena telur dan benih memiliki tingkat metabolisme yang tinggi. Kurangnya oksigen tidak hanya memperlambat perkembangan embrio tetapi juga dapat menimbulkan kematian embrio. Oksigen terlarut yang tinggi dapat meningkatkan pembuahan telur, penetasan telur, dan kelulushidupan awal larva ikan Tawas. Saat proses penetasan, telur membutuhkan oksigen untuk kelangsungan hidupnya dan untuk mempengaruhi embrio.

\section{KESIMPULAN DAN SARAN \\ Kesimpulan}

Kesimpulan yang didapat dari penelitian ini yaitu sebagai berikut :

1. Pemberian madu dengan dosis berbeda dalam media pengencer $\mathrm{NaCl}$ Fisiologis berpengaruh nyata $(\mathrm{p}<$ $0,05)$ terhadap fertilisasi (FR) dan hatching rate (HR) ikan tawes.

2. Perlakuan $\mathrm{D}(0,6 \mathrm{~mL}$ madu $+99,4 \mathrm{~mL} \mathrm{NaCl}$ Fisiologis $)$ memberikan nilai terbaik pada fertilisasi ikan tawes yaitu $90,67 \%$ dan pada hatching rate ikan tawes yaitu sebesar $86,67 \%$.

\section{Saran}

Saran yang dapat diberikan dari penelitian ini yaitu sebagai berikut :

1. Sebaiknya perlu digunakan penambahan madu dalam pengencer $\mathrm{NaCl}$ fisiologis dengan dosis terbaik yaitu 0,6 mL madu + 99,4 mL NaCl Fisiologis

2. Sebaiknya perlu dilakukan penelitian lebih lanjut mengenai pengenceran sperma menggunakan bahan pengencer lainnya dan mengamati jumlah spermatozoa ikan tawes untuk meningkatkan validitas hasil.

\section{Ucapan Terima Kasih}

Terima kasih penulis ucapkan kepada Bapak Bambang, Ibu Dewi, dan Bapak Mahmudi yang telah menyediakan fasilitas dan membantu berjalannya penelitian, serta teman-teman yang telah membantu penyusunan makalah ini

\section{DAFTAR PUSTAKA}

Adalina, Y. 2017. Kualitas Madu Putih Asal Provinsi Nusa Tenggara Barat. Pros Sem Nas Masy Biodiv Indon, 3(2):189-193.

Arifiantini, R. I. 2012. Teknik Koleksi dan Evaluasi Semen pada Hewan. IPB Press, Bogor, 92 hlm.

Akbar, U. F. 2014. Kajian Kualitas Spermatozoa Ikan Tawes (Barbonymus gonionotus, Bleeker 1849) yang Berasal Dari Dua Kolam Budidaya Berbeda. [Skripsi]. Fakultas Perikanan dan Ilmu Kelautan, Institut Pertanian Bogor, Bogor, $31 \mathrm{hlm}$.

Arfah, H., F. Hasan, dan M. Setiawati. 2015. Pemberian berbagai jenis madu dengan rasio pengenceran berbeda terhadap kualitas sperma Pangasianodon hypopthalmus. Jurnal Akuakultur Indonesia, 14(2):164-170.

Badan Pusat Statistik Kabupaten Sleman. 2016. Data Perkembangan Produksi Ikan Air Tawar.

Bozkurt, Y., F. Ogretmen, F. S. Secer dan U. Ercin. 2009. Relationship Between Seminal Plasma Composition and Spermatological Parameters in Scaly Carp (Cyprinus carpio). Journal of Animal and Veterinary Advances, 8(12):2745-2749.

Effrizal, A. 1998. Pengaruh Penyuntikan Ovaprim Terhadap Kualitas Telur Ikan Lele Lokal (Clarias batrachus). Fishieries Journal Garing, 7(2):1-10.

Farida, Rachimi dan Adrianus. 2016. Pengaruh Suhu yang Berbeda Terhadap Waktu Penetasan dan Kelangsungan Hidup Larva Ikan Biawan (Helostoma temmincki). Jurnal Ruaya, 4(2):63-69.

Hijriana, D. D. 2014. Pengaruh Media Pengencer NaCl Fisiologis dan Kuning Telur Sitrat terhadap Persentase Viabilitas dan Motilitas Spermatozoa Lele Dumbo (Clarias gariepinus). [Skripsi]. Fakultas Kedokteran Hewan, Universitas Airlangga, Surabaya.

Hutagalung, J., H. Alawi dan Sukendi. 2017. Pengaruh Suhu dan Oksigen Terhadap Penetasan Telur dan Kelulushidupan Awal Larva Ikan Pawas (Osteochilus hasselti C.V.). JOM, 4(1):1-12.

Kordi, K. M. G. H. 2010. Buku Pintar Pemeliharaan 14 Ikan Air Tawar Ekonomis di Keramba Jaring Apung. Ed. I. Lily Publisher, Yogyakarta, 214-215 hlm. 
Kurniawan, I. Y., F. Basuki, dan T. Susilowati. 2013. Penambahan Air Kelapa dan Gliserol Pada Penyimpanan Sperma Terhadap Motilitas dan Fertilitas Spermatozoa Ikan Mas (Cyprinus Carpio L.). Journal of Aquaculture Management and Technology, 2(1):51-65.

Lismawati, N., A. Hendri dan Mahendra. 2016. Fertilisasi dan Daya Tetas Telur Ikan Tawes (Puntius javanicus) dari Sperma Pasca Penyimpanan pada Temperatur $4^{\circ} \mathrm{C}$. Jurnal Perikanan Tropis, 3(1):77-84.

Maulana, F., Alimuddin, dan M. Z. Junior. 2014. Morfologi, Fisiologi, Preservasi Sel Sperma Ikan Betok, Anabas testudineus Bloch 1792 dan Ketahanannya Terhadap Kejut Listrik. Jurnal Ikhtiologi Indonesia, 14(3):211-223.

Nainggolan, R., R. D. Monijung, dan W. Mingkid. 2015. Penambahan Madu dalam Pengenceran Sperma untuk Motilitas Spermatozoa, Fertilisasi dan Daya Tetas Telur Ikan Nila (Oreochromis niloticus). Jurnal Budidaya Perairan, 3(1):131-140.

Nurman. 1998. Pengaruh Penyuntikan Ovaprim Terhadap Kualitas Spermatozoa Ikan Lele Dumbo (Clarias Gariephynus B). Garing, 7(2): 3-42.

Rachimi, E. I. Raharjo dan M. Syaidi. 2016. Rasio Penambahan Madu Dalam NaCl untuk Pengenceran Sperma Terhadap Fertilisasi dan Daya Tetas Telur Ikan Tengadak (Barbonymus schwanenfeldii). Jurnal Ruaya, 4(1):39-44.

Setiadi, A. N. S. 2001. Mempelajari Penggunaan Cairan Pikel Ketimun Sebagai Sumber Bakteri Asam Laktat Pada Pembuatan Bekasam Ikan Tawes (Puntius javanicus). [Skripsi]. Fakultas Perikanan dan Ilmu Kelautan, Institut Pertanian Bogor, Bogor, 81 hlm.

SNI. 1999. Produksi Benih Ikan Mas (Cyprinus carpio Linneaus) strain Majalaya kelas benih sebar. Badan Standarisasi Nasional. SNI 01- 6133 - 1999.

Sumardi, Y. dan D. Rosada. 2007. Biofisika. Ed. I. Universitas Terbuka, Banten

Susilawati, T. 2011. Spermatologi. Ed. 1. Universitas Brawijaya Press, Malang, 163 hlm.

Tumanung, S., H. J. Sinjal, dan J. C. Watung. 2015. Penambahan Madu dalam Pengenceran Sperma untuk Meningkatkan Motilitas, Fertilisasi dan Daya Tetas Telur Ikan Mas (Cyprinus carpio L). Jurnal Budidaya Perairan, 3(1):51-58.

Utami, I. P. 2010. Fertilisasi Spermatozoa Ikan Tawes (Barbonymus gonionotus, Bleeker 1850) Satu Hari Pascakriopreservasi Menggunakan Campuran Metanol dan Susu Skim sebagai Krioprotektan. [Skripsi]. Fakultas Matematika dan Ilmu Pengetahuan Alam, Universitas Indonesia, Depok, 76 hlm.

Wulandari, D. D. 2017. Kualitas Madu (Keasaman, Kadar Air, dan Kadar Gula Pereduksi) Berdasarkan Perbedaan Suhu Penyimpanan. Jurnal Kimia Riset, 2(1):16-22.

Zairin, M. J., R. K. Sari dan M. Raswin. 2005. Pemijahan Ikan Tawes dengan Sistem Imbas Menggunakan Ikan Mas sebagai Pemicu. Jurnal Akuakultur Indonesia, 4(2):103-108. 